\title{
A new approach to flood risk assessment in Asia-Pacific region based on MRI-AGCM outputs
}

\author{
Youngjoo Kwak ${ }^{1}$, Kuniyoshi Takeuchi ${ }^{1}$, Kazuhiko Fukami ${ }^{1}$ and Jun Magome ${ }^{2}$ \\ ${ }^{1}$ International Centre for Water Hazard and Risk Management (ICHARM) under the auspices of UNESCO, \\ Public Works Research Institute (PWRI), Japan \\ ${ }^{2}$ International Research Center for River Basin Environment (ICRE), University of Yamanashi, Japan
}

\begin{abstract}
:
Climate change is anticipated to escalate flood impacts, and thus it is important to assess flood risk closely in terms of extent and location. This study aimed to assess present and future flood risks, particularly flood risk change, over the Asia-Pacific region with consideration of climate change impacts by using a topography-based analysis method. By analyzing the output of the super-high-resolution global atmospheric general circulation model, it was found that future flood risk will increase in response to extreme rainfall under climate change. Results of this study also indicated that flood risk will further increase in the far future (20752099) than in the near future (2015-2039). Analyses of inundation area and flood inundation depth (FID) also showed upward trends; most of flood plains in the AsiaPacific region may experience a $0-50 \mathrm{~cm}$ increase in FID.
\end{abstract}

KEYWORDS climate change; flood risk; MRI-AGCM; Asia-Pacific region; FID

\section{INTRODUCTION}

There is a worldwide concern of increasing flood risks under anticipated climate change. Both the frequency and magnitude of flood hazards are expected to increase due to climate changes as a result of greenhouse gas-induced changes in temperature, radiation, rainfall, soil moisture and many other atmospheric factors (IPCC AR4, 2007; Petrow et al., 2001; Schiermeier, 2011), which will directly contribute to increasing flood disaster risk (Parry et al., 2001; Schipper and Pelling, 2006; Mirza, 2011). Moreover, Hirabayashi and Kanae (2009) emphasized that floodaffected population may well be larger at the global level considering a critical level of projected temperatures in the future. The Asia-Pacific region is particularly vulnerable to the impacts of natural disasters (World Bank, 2005). During 2000-2011, 9 of the top 10 countries with the highest number of water-related disaster deaths were in Asia (EM-DAT, 2012). Moreover, in 2003 alone, about 315-million of population was affected by tropical cyclones and floods (UNDP, 2004). Similar estimates were also provided by the Water World Assessment Program report (WWAP, 2009). Considering these circumstances, flood risk should be assessed not only from a single perspective of hazard intensity, but also from multiple viewpoints of hazards,

Correspondence to: Youngjoo Kwak, International Centre for Water Hazard and Risk Management (ICHARM) under the auspices of UNESCO, Public Works Research Institute (PWRI), 1-6 Minamihara, Tsukuba, Ibaraki 3058516, Japan. E-mail: kwak55@pwri.go.jp (C2012, Japan Society of Hydrology and Water Resources. damage and other socio-economic factors.

Flood risk has been studied as one of the major impacts of climate changes. However, closer examination is needed with different methods and climate scenarios to obtain more detailed information on the potential changes in flood risk, as well as the extent and location of inundated areas. Previous research has confirmed a possible increase in flood risk, but few studies have utilized global- or continental-scale inundation models under climate change. In an attempt to fill this gap, Kwak et al. (2011) developed a simple method for assessing the inundation depth based on topographical analyses.

Future flood risk also needs to be assessed in terms of different climate change scenarios. Simulations based on different scenarios produce different projections in future flood risk. Recently, a global climate model with a high horizontal grid resolution of about $20 \mathrm{~km}$ has been developed by the Japan Meteorological Agency (JMA). This model improves the simulation of regional-scale atmospheric processes and local climate due to better representation of topographical effects and physical processes (Mizuta et al., 2006; Kusunoki et al., 2011).

This study aimed to assess present and future flood inundation areas over the Asia-Pacific region under climate change by using a topography-based analysis method. More specifically, this study investigated to what extent the potential inundation area may change and where in the AsiaPacific region such flood risk may increase under future climate change condition. In addition, the flood risk change from the present to future was compared for two precipitation datasets MRI-AGCM3.1S and 3.2S. The output from 20-km resolution AGCM simulations (MRI-AGCM3.1S and 3.2S) was used. This study allows us to project potential future flood risk in relation to the future climate change.

\section{GLOBAL DATASET}

Figure 1 shows an overview of a dataset and study flow for computing potential inundation area by using the global dataset in this study.

\section{MRI-AGCM3. $1 S$ and $3.2 S$}

MRI-AGCM3.1S and 3.2S are the precipitation data used in this study to produce discharge data for each study period of time: Present (daily data from 1980 to 2004), Near Future (daily data from 2015 to 2039) and Far Future (daily data from 2075 to 2099) (Kitoh et al., 2009). MRI-AGCM3.1S

Received 12 March, 2012 Accepted 25 May, 2012 
is the output of a super high-resolution global atmospheric general circulation model on the Earth Simulator (Mizuta et al., 2006), jointly developed by the Japan Meteorological Agency (JMA) and the Meteorological Research Institute (MRI), with a horizontal grid size of about $20 \mathrm{~km}$ and 60 vertical layers (top $0.1 \mathrm{hPa}$ ). MRI-AGCM3.2S is a slightly revised version of MRI-AGCM3.1S with improvement particularly in the frequency of tropical cyclones in the western North Pacific and seasonal change of the East Asian Summer Monsoon by changing the parameters shown in Table I (Mizuta et al., 2012). Table I lists the difference in the specification between MRI-AGCM3.1S and MRIAGCM3.2S. Inomata et al. (2011) corrected the bias of MRI-AGCM precipitation datasets by using grid-based APHRODETE daily precipitation datasets estimated from a rain-gauge-observation network.

\section{BTOP model parameters}

The BTOP distributed hydrological model used in this study was originally developed by Takeuchi et al. (1999) for the purpose of hydrological simulations over large river basins (Takeuchi et al., 2008; Shrestha et al., 2007; Hapuarachchi et al., 2011). For calculating inundation

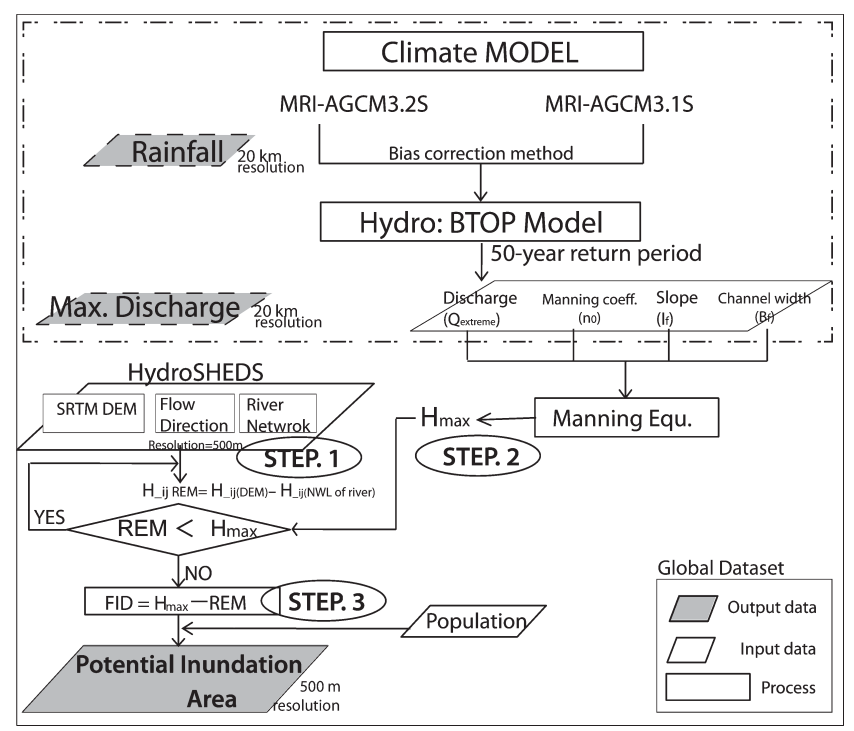

Figure 1. Integrated analysis flowchart for computing potential inundation area. depths, the study used the Manning's roughness coefficient $\left(n_{0}\right)$, the local channel slope $\left(I_{f}\right)$ width $\left(B_{f}\right)$ and the maximum daily discharge $\left(Q_{\max }\right)$ of the BTOP model with the Muskingum-Cunge method (Cunge, 1969). The BTOP discharge datasets were created for this study from MRIAGCM3.1S and 3.2S.

\section{HydroSHEDS}

The Shuttle Elevation Derivatives at multiple Scale (HydroSHEDS) is produced by the NASA's Shuttle Radar Topography Mission (SRTM) (Farr et al., 2007) in a consistent format for regional- and global-scale applications (Lehner et al., 2006). The elevation layers, i.e., DEM (digital elevation model), are based on a combination of the original SRTM-3 and the digital terrain elevation data (DTED-1) of SRTM. In this study, DEM, main streams and flow directions were used to calculate potential inundation areas at 15 arcsecond resolution (approximately 500 meters at the equator).

\section{LandScan 2009}

The study employed population data derived from the LandScan2009 Global Population Database at 30 arc seconds (1 km or finer), developed by the Oak Ridge National Laboratory (ORNL) for the United States Department of Defense (DoD). The LandScan is the finest population data available which describe both distribution and dynamics (day and night) of human population by using geospatial and temporal modeling for a high degree of location accuracy (Budhendra et al., 2007).

\section{METHODOLOGY}

\section{Study area}

As the target study area, the Asia-Pacific region between $50 \mathrm{~N}-10 \mathrm{~S}$ and $65 \mathrm{E}-150 \mathrm{E}\left(32,000,000 \mathrm{~km}^{2}\right)$ was selected. This area covers about $21 \%$ of the world's land area with large rivers such as Ganges, Indus, Chang Jiang and Mekong. This region is extremely prone to flood disasters, especially the areas affected by Asian monsoons and typhoons/ cyclones.

\section{Definition of flood risk}

Many factors are involved in defining flood risk. In this study, as described in the introduction, the authors defined flood risk $\left(\right.$ RISK $\left._{\text {flood }}\right)$ as follows:

Table I. Specifications of the new and previous versions of MRI-AGCM projection

\begin{tabular}{|c|c|c|}
\hline & MRI-AGCM3.1S & MRI-AGCM3.2S \\
\hline Horizontal resolution & & TL959 $(20 \mathrm{~km}, 1920 \times 960)$ \\
\hline Vertical levels & $60($ top at $0.1 \mathrm{hPa})$ & 64 (top at $0.01 \mathrm{hPa}$ ) \\
\hline Time step & 6 minutes & 10 minutes \\
\hline Cumulus convection & Prognostic Arakawa-Schubert (1974) & Yoshimura (2005) \\
\hline Cloud & Smith (1990) & Tiedtke (1993) \\
\hline Radiation & Shibata and Aoki (1989) & JMA (2007) \\
\hline & Shibata and Uchiyama (1992) & \\
\hline Gravity wave drag & \multicolumn{2}{|r|}{ Iwasaki et al. (1989) } \\
\hline Land surface & \multirow{2}{*}{\multicolumn{2}{|c|}{$\begin{array}{l}\text { Hirai et al. (2007) } \\
\text { Mellor and Yamada (level 2) (1974) }\end{array}$}} \\
\hline Boundary layer & & \\
\hline Aerosol (direct) & Sulfate aerosol & Five species \\
\hline
\end{tabular}




$$
\begin{aligned}
& \operatorname{RISK}_{\text {flood }} \\
& \quad=\text { function } \\
& \left(\text { Hazard }_{\text {flood }}, E X P_{\text {population }}, V_{\text {busic }}\right)
\end{aligned}
$$

where RISK $_{\text {flood }}$ is the flood risk of the area, Hazard flood $_{\text {is }}$ the potential inundation area, EXP population is the maximum number of affected people in the inundation area, and $V u l_{\text {basic }}$ is the basic vulnerability of the inundation area. This definition of flood risk has been widely adopted in other studies (Crichton, 1999; UNDP, 2004; ADRC, 2005). In this study, the potential inundation area was calculated by the annual maximum daily river discharge with a $1 / 50$ probability of occurrence (50-year flood). The flood risk of the inundation area was simulated by assuming the maximum value for the vulnerability factor due to unavailability of data such as coping capacity, resilience, and susceptibility.

\section{Procedure}

Figure 1 shows the outline of the procedure of this study. Input data at each grid cell adjusted to the employed GIS were calculated from the original data given at original grid cell. The following steps describe the preparation of necessary data to finally compare Present, Near Future and Far Future flood risks.

\section{Step 1: Derivation of relative elevation model (REM)}

To calculate flood risk according to the definition above, data for Hazard flood need to be prepared. In this study, the authors used flood inundation depth (FID) for this hazard factor. As shown in Figure 2, the relative elevation model (REM) of each cell is needed in order to obtain FID. The REM of an individual cell in the study area was derived from the elevation difference between the cell and its nearest downstream given river channel cell (target cell), based on the HydroSHEDS data (Figure 2(1)) by using the aforementioned topography-based method (Kwak et al.,

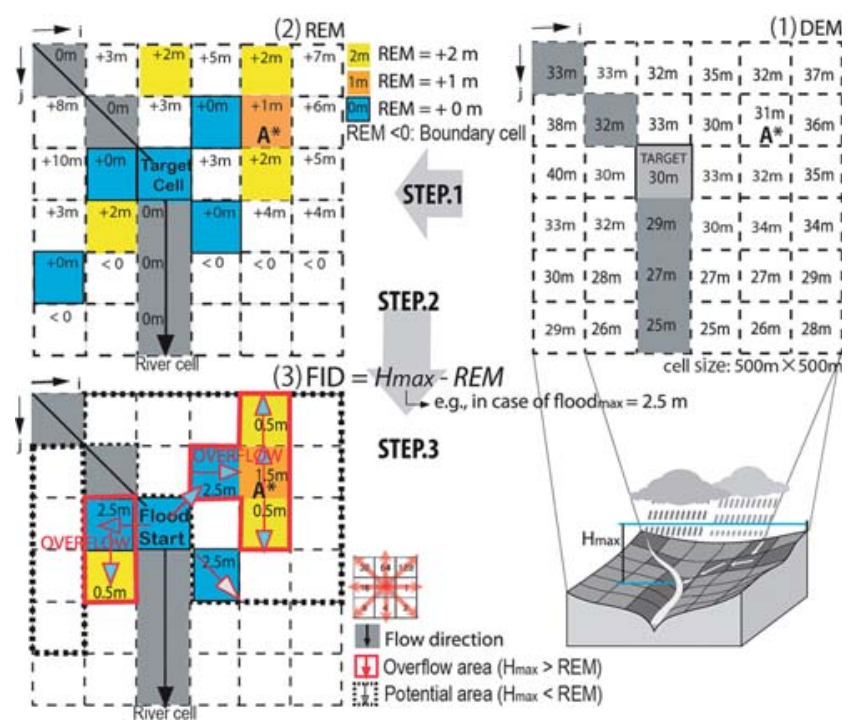

Figure 2. Schematic diagram of the simple algorithm for computing potential flood inundation depths by using DEM, flow direction and river network in step 1. In Step 3 FID, the floodwaters in the target cell can overflow to its surrounding cells in 8 directions, depending on their DEM values.
2010). Figure 2(2) shows a sample case of calculating the REM of the cells around a given river channel cell. In this case, the elevations of the river channel cell (target cell) and cell $\mathrm{A}^{*}$ are $30 \mathrm{~m}$ and $31 \mathrm{~m}$, respectively; thus, the REM of cell $\mathrm{A}^{*}$ is $+1 \mathrm{~m}$. Accordingly, REM are determined for other cells.

However, REM is only capable of expressing depth with the accuracy of $1 \mathrm{~m}$ due to the limitation of HydroSHED15S/ DEM. Improvement is necessary for REM to achieve a depth accuracy of less than $1 \mathrm{~m}$ by applying linear interpolation. Also, the DEM data are not capable of expressing mainstream banks (including artificial embankments), which also affects the accuracy of the FID model.

Step 2: Production of $H_{\text {max }}$

$\mathrm{H}_{\text {max }}$ was set as the maximum river water depth of the 50 -year flood calculated based on MRI-AGCM 3.1S or 3.2S. $\mathrm{H}_{\max }$ was calculated only for river channel cells. This dataset was produced by transforming from the BTOP discharge data by using Manning's steady, uniform flow resistance formula below (Chow et al., 1988; Hapuarachchi et al., 2011):

$$
H_{\text {max }}=\left\{Q_{\text {max }} \times n_{0} /\left(B_{f} \times I_{f}^{1 / 2}\right)\right\}^{0.6}
$$

Step 3: Calculation of FID

After determining $\mathrm{H}_{\max }$ for each river channel cells, FID was calculated for each cell as the difference between $\mathrm{H}_{\text {max }}$ and REM (FID $\left.=H_{\max }-\mathrm{REM}\right)$. FID indicates the potential flood inundation depth of a given cell when $\mathrm{H}_{\max }$ is greater than the REM of that cell (REM $\left.<H_{\max }\right)$. In the case of $\mathrm{REM} \geqq \mathrm{H}_{\text {max }}$, FID was not calculated because it means that no flooding is expected to occur over such cells.

Figure 2(3) illustrates how FID was derived for cells around a given river channel cell. The floodwater flows into the next cell with the lowest REM among those adjacent to the previous one.

Step 4: Calculation and comparison of RISK flood

Finally, the potential flood risk of each flooded cell was determined by applying the calculated FID, as well as the hazard and exposure factors, to equation (1). In this study, the exposure factor was a function of the geographic distribution of population per square kilometers exposed to a given flood inundation area, based on the LandScan dataset.

The authors performed time-slice simulation for three different periods of time by repeating the procedure above to obtain flood risks in the respective cases of Present, Near Future and Far Future, and then compared them between MRI-AGCM3.1S and 3.2S for possible flood-risk change.

To this end, differential FID was calculated by subtracting the FID in Present from the FID in Near Future or Far Future. With the calculated flood risk in Present used as the benchmark, potential flood risk changes in Near Future and Far Future were estimated.

\section{RESULTS}

Figure 3 shows the overall results of this study. Figure $3 \mathrm{a}$ and $\mathrm{b}$ are the maps of 50-year flood inundation comparing Present, Near Future and Far Future of MRI-AGCM3.1S projection while Figure $3 \mathrm{c}$ and $\mathrm{d}$ for Present, Near Future and Far Future of MRI-AGCM3.2S. Table II shows the projected inundation area and population in flood risk areas, 


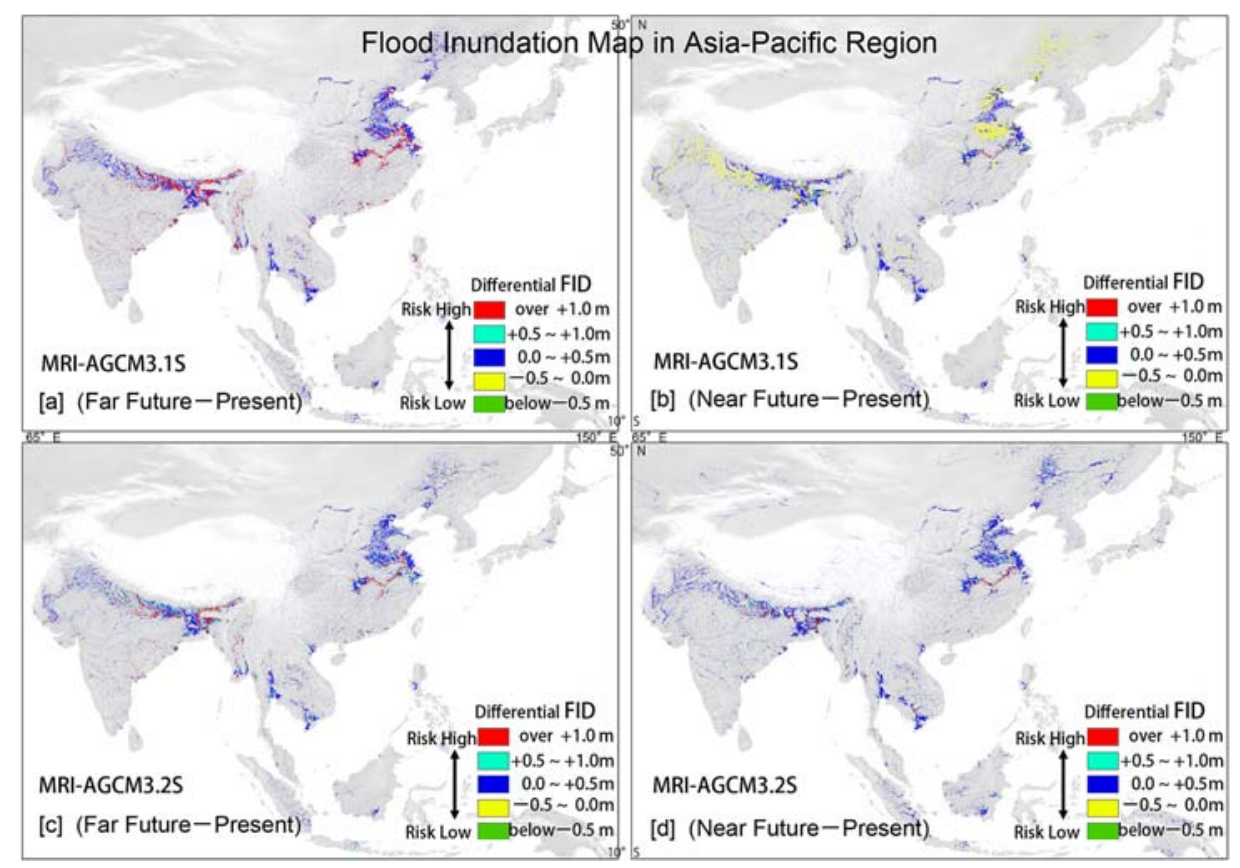

Figure 3. Potential inundation areas in the Asia-Pacific region (50N-10S, 65E-150E), cases of Near Future and Far Future based on (a) and (b) of MRI-AGCM3.1S or (c) and (d) of MRI-AGCM3.2S. In the most of the potential inundation area (a, c and d), the inundation depth increase (differential FID) between $0 \mathrm{~cm}$ and $50 \mathrm{~cm}$ compared with the present flood. On the other hand, in Near Future (b), a differential FID of less than zero meters is clearly visible over the potential inundation area.

Table II. Potential 50-year flood inundation area in the Asia-Pacific region based on the BTOP model using the bias-corrected precipitation of MRI-AGCM3.1S or $3.2 \mathrm{~S}$

\begin{tabular}{|c|c|c|c|c|c|c|}
\hline \multirow{2}{*}{$\begin{array}{l}\text { Potential inundation } \\
\text { area }\end{array}$} & \multicolumn{3}{|c|}{ MRI-AGCM3.2 (Bias correction) } & \multicolumn{3}{|c|}{ MRI-AGCM3.1 (Bias correction) } \\
\hline & $\begin{array}{l}\text { Hazard area } \\
\left(\mathrm{km}^{2}\right)\end{array}$ & $\begin{array}{l}\text { Area }\left(\mathrm{km}^{2}\right) \text { where } \\
\text { FID increases }\end{array}$ & $\begin{array}{l}\text { Area }(\%) \text { where FID } \\
\text { increases over } 50 \mathrm{~cm}\end{array}$ & $\begin{array}{l}\text { Hazard area } \\
\left(\mathrm{km}^{2}\right)\end{array}$ & $\begin{array}{l}\text { Area }\left(\mathrm{km}^{2}\right) \text { where } \\
\text { FID increases }\end{array}$ & $\begin{array}{l}\text { Area }(\%) \text { where FID } \\
\text { increases over } 50 \mathrm{~cm}\end{array}$ \\
\hline SFAC (2075-2099) & $1,880,000$ & $1,490,000$ & +21.2 & $1,850,000$ & $1,500,000$ & +17.8 \\
\hline SNAC (2015-2039) & $1,840,000$ & $1,230,000$ & +8.9 & $1,793,000$ & 990,000 & +5.6 \\
\hline SPAC (1980-2004) & $1,810,000$ & & & $1,786,000$ & & \\
\hline
\end{tabular}

as well as their rate of changes, in Present, Near Future and Far Future projected by the cases of MRI-AGCM3.1S and $3.2 \mathrm{~S}$.

The projected 50-year flood inundation area increases from Present to Far Future in both cases (MRI-AGCM3.1S: 1.78 million $\mathrm{km}^{2}$ to 1.85 million $\mathrm{km}^{2}$; MRI-AGCM3.2S: 1.81 million $\mathrm{km}^{2}$ to 1.88 million $\mathrm{km}^{2}$ ) (Table II), but the potential flood hotspots where FID increases more than $1 \mathrm{~m}$ in Far Future (red cells in Figure 3) increase at a greater rate of $21.2 \%$ with MRI-AGCM3.2S compared with $17.8 \%$ with $3.1 \mathrm{~S}$.

Table II also shows the respective rates of flood-risk change from Present to Far Future for both AGCM cases. Overall, these results are mutually consistent in that increased rainfall is likely to contribute to higher flood risk, and that greater flood risk is expected toward Far Future. It is also interesting that, in Figure $3 \mathrm{a}$, the flood risk in Near Future stays at the same level as Present or shows a potential decrease. The yellow cells showing the negative differential FIDs are clearly visible over the potential flood area. This is due to a decrease in extreme rainfall projected in the case of MRI-AGCM3.1S. Since MRI-AGCM3.2S is a projection with more extreme rainfall than $3.1 \mathrm{~S}$, this result suggests that flood risk may show a greater increase if climate change results in more extreme rainfall.

Additionally, in an attempt to estimate affected people in the case of a 50-year flood based on the two global rainfall datasets, the authors found that, with both datasets, the number of affected people may also increase at a greater rate of $6.1 \%$ (approximately 35.1 million people) with MRIAGCM3.2S from Present to Far Future, compared with 4.9\% (approximately 27.9 million people) with $3.1 \mathrm{~S}$.

Furthermore, it may be worth noticing that flood risk hotspots spread mainly in the downstream areas of the following rivers: Indus (Pakistan), Ganges (North of India), Chang Jiang (eastern China), Ayeyarwady (Myanmar), lower Mekong (Cambodia and Viet Nam), and Amur (China) in monsoon Asia, as shown in Figure $3 a$ and $b$.

\section{CONCLUSION}

In this study, the authors developed the simple topography-based analysis method for flood risk assessment 
over the Asia-Pacific region under climate change. Flood risk assessment was conducted using a $20-\mathrm{km}$ resolution global atmospheric model outputs, focusing on the assessment of Present, Near Future and Future flood risks, particularly changes of flood inundation area according to FID, over the Asia-Pacific region with consideration of climate change impacts. The study found that flood risk may show a greater increase if climate change results in more extreme rainfall. In the future climate simulation by MRIAGCM3.2S, the change of flood risk is consistent with extreme rainfall. Analyses were conducted by dataset and time period in terms of flood-risk area, affected population and their change rates. Their results showed an upward trend.

For future regional flood risk assessment, improvement is necessary to increase accuracy in identification of flood inundation area by calibrating local hydro-geomophological parameters. In addition, the BTOP outputs of flood timeseries, which are the basis of this analysis, need further improvement in the processes of, for example, evapotranspiration and snowmelt mechanisms. Furthermore, the study should be extended to basins less than $5,000 \mathrm{~km}^{2}$ and mega deltas located in coastal areas.

Finally, the prospective change of flood risk should be examined more closely under various climate change scenarios. In addition, large-scale assessment results, such as those of this study, should be validated through smallerscale assessment, for example, by studying a specific local river basin.

\section{ACKNOWLEDGEMENTS}

This work was conducted under the framework of the "assessment of the impact of climate change on flood disaster risk and its reduction measures over the globe and specific vulnerable areas (C-09)" under the "projection of the change in future weather extremes using super-high-resolution atmospheric models" (PI: Akio Kitoh) of Meteorological Research Institute (MRI) of Japan supported by the Innovative Program of Climate Change Projection for the 21 st Century (KAKUSHIN) of the Ministry of Education, Culture, Sports, Science, and Technology (MEXT), Japan.

\section{SUPPLEMENT}

Supplement 1. Relationship between precipitation and maximum daily discharge related to flood risk.

Figure S1. Differences (=Far Future-Present) of Top $0.5 \%$ bias-corrected daily precipitation (a) and maximum daily discharge projected (b) in the case of MRIAGCM3.2S.

Figure S2. Enlarged version of Figure 3c showing difference FID (=Far Future-Present) based on MRIAGCM3.2S.

\section{REFERENCES}

ADRC. 2005. Total Disaster Risk Management: Good Practices, Asian Disaster Reduction Center, 1-89. http://www.adrc.asia/ publications/TDRM2005/TDRM_Good_Practices/GP2005_e.html.
Last access November 11, 2011.

Arakawa A, Schubert WH. 1974. Interaction of cumulus cloud ensemble with the large-scale environment. Part I. Journal of the Atmospheric Sciences 31: 674-701. doi: 10.1175/15200469(1974)031<0674:IOACCE>2.0.CO;2.

Budhendra B, Bright E, Coleman P, Urban M. 2007. LandScan USA: a high-resolution geospatial and temporal modeling approach for population distribution and dynamics. GeoJournal 69: 103-117. doi: 10.1007/s10708-007-9105-9.

Chow V, Maidment D, Mays L. 1988. Applied Hydrology. New York, McGraw-Hill Book, 572 pp.

Crichton D. 2008. Role of insurance in reducing flood risk, The Geneva papers on risk and insurance - Issues and Practice 33: 117-132. doi: 10.1057/palgrave.gpp. 2510151.

Cunge J. 1969. On the subject of a flood propagation computation method (Muskingum method). Journal of Hydraulic Researches 7: 205-230.

EM-DAT. 2012. Disaster list published by super Admin-Emergency event Database. The OFDA/CRED International Disaster Database. http://www.emdat.be/disaster-list. Last access March 10, 2012.

Farr TP, Rosen PA, Caro E, Crippen R, Duren R, Hensley S, Kobrick M, Paller M, Rodriguez E, Roth L, Seal D, Shaffer S, Shimada J, Umland J, Werner M, Oskin M, Burbank D, Alsdorf D. 2007. The shuttle radar topography mission. Review of Geophysics 45, RG2004. doi: 10.1029/ 2005RG000183.

Hapuarachchi HAP, Wang QJ, Pagano TC. 2011. A review of advances in flash flood forecasting. Hydrological Process 25 : 2771-2784. doi: 10.1002/hyp.8040.

Hirabayashi Y, Kanae S. 2009. First estimate of the future global population at risk of flooding. Hydrological Research Letters 3: 6-9. doi: 10.3178/hrl.3.6.

Hirai M, Sakashita T, Kitagawa H, Tsuyuki T, Hosaka M, Ohizumi M. 2007. Development and validation of a new land surface model for JMA's operational global model using the CEOP observation dataset. Journal of the Meteorological Society of Japan 85A: 1-24. doi: 10.2151/jmsj.85A.1.

Inomata H, Takeuchi K, Fukami K. 2011. Development of a statistical bias correction method for daily precipitation data of GCM20. Annual Journal of Hydraulic Engineering 55: 247-252. doi: 10.2208/jscejhe.67.I_247.

IPCC. 2007. Climate Change 2007: Impacts, Adaptation and Vulnerability. Contribution of Working Group II to the Fourth Assessment Report of the Intergovernmental Panel on Climate Change, Cambridge University Press, Cambridge, UK; 780 810. ISBN: $978052188010-7$.

Iwasaki T, Yamada S, Tada K. 1989. A parameterization scheme of orographic gravity wave drag with the different vertical partitioning, part 1: Impact on medium range forecast. Journal of the Meteorological Society of Japan 67: 11-27. doi: $10.2151 / \mathrm{jmsj} 1965 / 67.11$.

Japan Meteorological Agency. 2007. Outline of the operational numerical weather prediction at the Japan Meteorological Agency (Appendix to WMO numerical weather prediction progress report). 194 pp. http://www.jma.go.jp/jma/jma-eng/ jma-center/nwp/outline-nwp/index.htm. Last access January 3, 2012.

Kitoh A, Ose T, Kurihara K, Kusunoki S, Sugi M, KAKUSHIN Team-3 Modeling Group. 2009. Projection of changes in future weather extremes using super-high-resolution global and regional atmospheric models in the KAKUSHIN Program: Results of preliminary experiments. Hydrological Research Letters 3: 49-53. doi: 10.3178/hrl.3.49.

Kusunoki S, Mizuta R, Matsueda M. 2011. Future changes in the East Asian rain band projected by global atmospheric models with 20-km and 60-km grid size. Climate Dynamics 37: 24812493. doi: 10.1007/s00382-011-1000-x. 
Kwak Y, Kondoh A. 2010. A Study on the Assessment of MultiFactors Affecting Urban Floods Using Satellite Image: A Case Study in Nakdong Basin, S. Korea. Advances in Geosciences 17: Hydrological Science, World Scientific Publishing; 265-278. ISBN: 978-981-283-811-7.

Kwak Y, Hasegawa A, Inomata H, Magome J, Fukami J, Takeuchi K. 2011. A New Assessment Methodology for Flood Risk: A Case Study in the Indus River Basin, Risk in Water Resources Management 347. Blöeschl G (eds). IAHS Press; 55-60. ISBN: 978-1-907161-22-3.

Lehner B, Verdin K, Jarvis A. 2006. HydroSHEDS Technical Documentation. Version 1.0, World Wildlife Fund US, Washington, DC: 1-27. http://hydrosheds.cr.usgs.gov. Last access November 11, 2011.

Mellor GL, Yamada T. 1974. A hierarchy of turbulence closure models for planetary boundary layers. Journal of the Atmospheric Sciences 31: 1791-1806. doi: 10.1175/15200469(1974)031<1791:AHOTCM>2.0.CO;2.

Mirza MMQ. 2011. Climate change, flooding in South Asia and implications. Regional Environmental Change 11: 95-107. doi: 10.1007/s10113-010-0184-7.

Mizuta R, Oouchi K, Yoshimura H, Noda A, Katayama K, Yukimoto S, Hosaka M, Kusunoki S, Kawai H, Nakagawa M. 2006. 20km-mesh global climate simulations using JMAGSM model - Mean climate states -. Journal of the Meteorological Society of Japan 84: 165-185. doi: 10.2151/ jmsj.84.165.

Mizuta R, Yoshimura H, Murakami H, Matsueda M, Endo H, Ose T, Kamiguchi K, Hosaka M, Sugi M, Yukimoto S, Kusunoki S, Kitoh A. 2012. Climate simulations using MRI-AGCM3.2 with 20-km grid. Journal of the Meteorological Society of Japan 90A: 233-258. doi: 10.2151/jmsj.2012-A12.

Parry M, Arnell N, McMichael T, Nicholls R, Martens P, Kovats S, Livermore M, Rosenzweig C, Iglesias A, Fischer G. 2001. Millions at risk: defining critical climate change threats and targets. Global Environmental Change 11: 181-183. doi: 10.1016/S0959-3780(01)00011-5.

Petrow T, Zimmer J, Merz B. 2001. Changes in the flood hazard in Germany through changing frequency and persistence of circulation patterns. Natural Hazards and Earth System Sciences 9: 1409-1423. doi: 10.1016/j.jhydrol.2009.03.024.

Schiermeier Q. 2011. Increased flood risk linked to global warming. Nature 470: 316 . doi: 10.1038/470316a.

Schipper L, Pelling M. 2006. Disaster risk, climate change and international development: scope for, and challenges to, integration. Disasters 30: 19-38. doi: 10.1111/j.14679523.2006.00304.x.
Shibata K, Aoki T. 1989. An infrared radiative scheme for the numerical models of weather and climate. Journal Geophysical Research 94D12: 14923-14943. doi: 10.1029/ JD094iD12p14923.

Shibata K, Uchiyama A. 1992. Accuracy of the delta-four-stream approximation in inhomogeneous scattering atmospheres. Journal of the Meteorological Society of Japan 70: 10971109. doi: JST.Journalarchive /jmsj1965/70.1097.

Shrestha S, Bastolab S, Babelc M, Dulalb K, Magomeb J, Hapuarachchid H, Kazamaa F, Ishidairab H, Takeuchi K 2007. The assessment of spatial and temporal transferability of a physically based distributed hydrological model parameters in different physiographic regions of Nepal. Journal of Hydrology 347: 153-172. doi: 10.1016/ j.jhydrol.2007.09.016.

Smith RNB. 1990. A scheme for predicting layer clouds and their water content in a general circulation model. Quarterly Journal of the Royal Meteorological Society 116: 435-460. doi: 10.1002/qj.49711649210.

Takeuchi K, Ao T, Ishidaira H. 1999. Introduction of block-wise use of TOPMODEL and Muskingum-Cunge method for the hydro-environmental simulation of a large ungauged basin. Hydrological Sciences Journal 44: 633-646. doi: 10.1080/ 02626669909492258 .

Takeuchi K, Hapuarachchi P, Zhou M, Ishidaira H, Magome J. 2008. A BTOP model to extend TOPMODEL for distributed hydrological simulation of large basins. Hydrological Processes 22: 3236-3251. doi: 10.1002/hyp.6910.

Tiedtke M. 1993. Representation of clouds in large-scale models. Monthly Weather Review 121: 3040-3061. doi: 10.1175/15200493(1993) $121<3040$ :ROCILS $>2.0$.CO;2.

UNDP. 2004. Reducing disaster risk: a challenge for development, a global report. United Nations Development programme, Bureau for Crisis and Recovery, John S. Swift; 1-117. ISBN 92-1-126160-0.

World Bank. 2005. Natural Disaster Hotspots: Case Studies, Disaster Risk Management Series; 1-184. ISBN 0-82136332-8.

World Water Assessment Programme. 2009. The United Nations World Water Development Report 3: Water in a Changing World. Paris: UNESCO Publishing and London: Earth scan; 2-24. http:// www.unesco.org/water/wwap/wwdr/wwdr3/. Last access March 10, 2012.

Yoshimura H, Matsumura T. 2005. A two-time-level verticallyconservative semi-Lagrangian semi-implicit double Fourier series AGCM. CAS/JSC WGNE Research Activities in Atmospheric and Ocean Modeling 35: 3.27-3.28. 